\title{
Meras Coisas e Artes do Espaço: DesconstruÇáo em Obras ${ }^{1}$
}

Alice Serra ${ }^{2}$

RESUMO: Este texto aborda alguns trabalhos contemporâneos em artes visuais (obras de G. Penone, R. Smithson, C. Casanovas) que apresentam diferentes relaçóes e disposiçóes de um material dito natural: pedras. Ao retomar as distinçôes explicitadas por Heidegger, entre meras coisas, utensílio e obra de arte, bem como entre a pedra, o animal e o homem em relação ao mundo, serão discutidos deslocamentos acerca dessas distinçôes, com base em apontamentos da desconstrução (Jacques Derrida e outros autores). Pretende-se indicar alguns dos sentidos em que os enfoques desconstrutivos são frutíferos, para se pensar movimentos contemporâneos no âmbito do que Derrida denomina artes do espaço.

PALAVRAS-CHAVE: Jacques Derrida. Martin Heidegger. Giuseppe Penone. Robert Smithson. Claudi Casanovas.

\section{INTRODUÇÃo}

A desconstrução apresenta-se como um pensamento das fronteiras e limites: limites arraigados na tradição filosófica, como as distinçóes entre ideal e real, fala e escrita, humano e não humano, arte e natureza, arte e utensílio. Para Derrida, não se trata somente de destruir tais oposiçóes ou de inverter os termos, colocando numa posição hierarquicamente superior o âmbito que teria sido relegado a um lugar marginal pelas filosofias logocêntricas. Para a desconstrução, urge também produzir ou intensificar diferenciações que sublinhem as incongruências internas aos sistemas, instituiçóes e discursos. Essas incongruências não são sempre apontadas de fora, mas podem ser trazidas à cena a partir da demora da desconstrução em textos da tradição, seja em

\footnotetext{
${ }^{1}$ http://dx.doi.org/10.1590/S0101-31732016000500008

${ }^{2}$ Professora Adjunta do Departamento de Filosofia da Universidade Federal de Minas Gerais (UFMG), vinculada à Graduação e à Pós-Graduação (Mestrado e Doutorado). Doutora em Filosofia pela AlbertLudwigs-Universität Freiburg, Alemanha; Mestre em Filosofia pela UFMG. Atua na área de Filosofia Contemporânea (Fenomenologia, Hermenêutica, Pós-Estruturalismo francês) e desenvolve pesquisa atual sobre artes visuais e desconstrução, com apoio da FAPEMIG e do CNPq. aliserr@gmail.com
} 
seus sentidos explícitos, seja no que se encontra nas entrelinhas, muitas vezes contrariando as intençóes afirmadas pelos próprios autores. Em detrimento da pretensão de algumas filosofias de ser um pensar conceitual sobre as demais dimensôes ônticas da experiência, a desconstrução desloca essa centralidade, ao trazer à filosofia interferências de outros âmbitos. E é nesse sentido que arte e desconstrução se tocam.

Em sua desconstrução da estética, Derrida insere, em alguns casos, processos performativos ímpares, como, por exemplo, em sua obra Enlouquecer o subjétil, feita em parceria com a artista plástica Lena Bergstein (DERRIDA; BERGSTEIN, 1998). É um livro pensado a partir de Artaud - o que é diferente de ser um livro sobre Artaud - de sorte que importava não simplesmente descrever ou analisar textos, grafias e imagens dos cadernos de Artaud, mas de repetir, diferindo algo que neles se encontrava. Assim, Derrida deixa as intervenções gráficas de Lena Bergstein ao lado de seu texto, como instância igualmente de pensamento. Para Derrida, a escrita tem um espaçamento próprio, como no recurso à pontuaçáo, intervalos que impedem a sua assunção pelo discurso fonologocêntrico.

Também nesse direcionamento, em seu texto La différance, Derrida (1972) procura mostrar que não é possível simplesmente traduzir a escrita pela palavra - ele troca o "a" e o "e", o que náo faz diferença para a palavra falada, mas é precisamente uma marca textual que resiste ao discurso - daí a necessidade de voltar à escrita, ao que, na escrita, na marca, não é somente significado e intenção de significado. Pensadas desde o espaçamento do traço, as artes do espaço (Derrida prefere propriamente esse termo para reportar-se às artes visuais) têm, para Derrida, o potencial de intensificar tal resistência ao discurso apropriativo e de questionar os limites entre as fronteiras. Como enuncia Derrida, acerca das artes espaciais:

[...] a questão das artes espaciais recebe proeminência, pois é no interior de uma certa experiência do espaçamento, do espaço, que a resistência à filosofia pode ser produzida. Em outras palavras, a resistência ao logocentrismo tem uma chance maior de aparecer nesses tipos de arte. (DERRIDA, 2012b, p. 20s.).

Com base em consideraçôes de Derrida e outros autores que partilham do enfoque desconstrutivo, como Didi-Huberman e Jean-Luc Nancy, este texto se volta à relação entre algumas artes do espaço, suas disposiçóes e delimitaçôes, enfocando mais propriamente um tópico específico: a disposição 
de pedras no espaço. Trabalhos contemporâneos como os de G. Penone, R. Smithson, C. Casanovas apresentam diferentes relaçóes e disposições desse material dito natural: pedras. Trata-se de retomar as distinçóes apresentadas por Heidegger, a propósito de coisas e arte, e de apontar para deslocamentos possíveis a respeito das mesmas, tanto através dos trabalhos dos artistas mencionados quanto dos autores referidos.

Mas eu gostaria de começar de modo situado, mostrando de onde essa questão partiu.

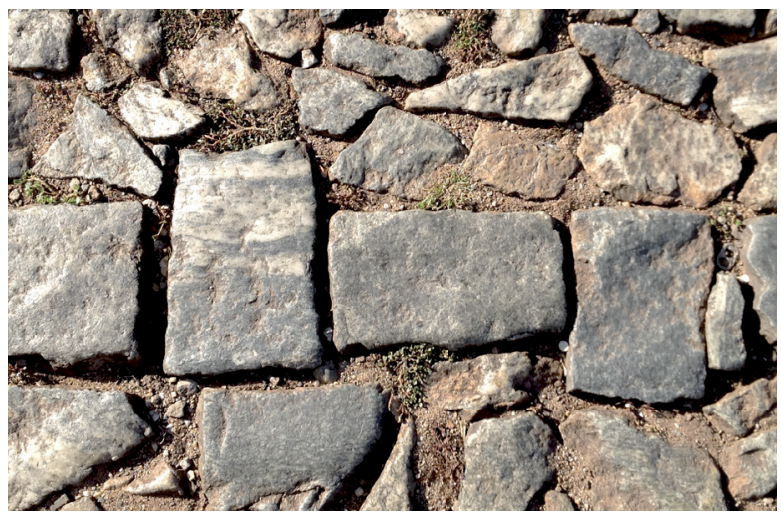

Rua de paralelepípedos, Sabará, MG

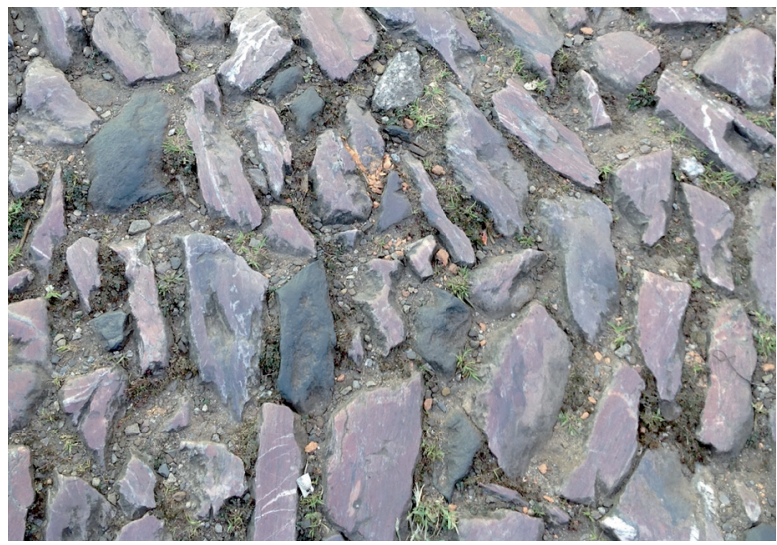

Rua de paralelepípedos, Sabará, MG 
Em Minas Gerais, é frequente encontrar, nas ruas de cidades históricas, tais como Sabará, Caeté, Ouro Preto, Tiradentes, pedras que se denominam paralelepípedos. Quanto mais antigas são as ruas, mais irregulares são os formatos, mais diversificados os cortes e tonalidades. Olhar para essas pedras sob nossos pés implica, às vezes, perguntar-se por sua proveniência ou por seu estatuto ontológico. Uma resposta habitual seria: tais paralelepípedos, separados dos blocos de pedras de que proviriam, foram extraídos de uma condição natural e deslocados para outra função: a de calçamento, quando teriam se tornado uma espécie de utensílio, ao facilitarem, por exemplo, o escoamento da chuva e a circulação de pedestres, ou ao refrearem o crescimento da vegetação nos lugares de trânsito, além de outras funçôes cabíveis. Nesse caso, tais paralelepípedos dispostos nas vias náo seriam nem simples pedras, nem obras de arte. $\mathrm{Na}$ terminologia heideggeriana, eles seriam utensílios ou artefatos (Zeug).

Todavia, antes de passarmos à distinção heideggeriana entre meras coisas, utensílios e artefatos, imaginemos já alguns deslocamentos possíveis, a partir dos quais os paralelepípedos perderiam sua função utensiliar: por exemplo, na situação em que fossem retirados das ruas e levados a uma sala de exposição, instalados fora de alguma funcionalidade.

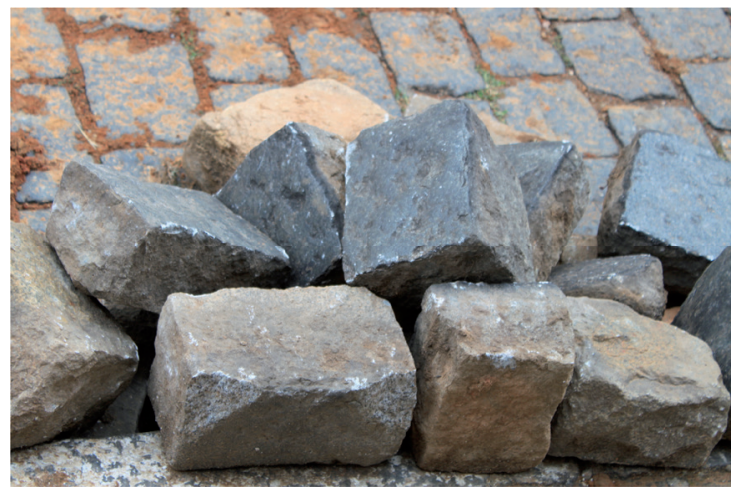

Paralelepípedos, São João Del Rei, MG

Uma descrição possível dessa circunstância seria uma repetição do agenciamento de Marcel Duchamp, ao retirar um produto fabricado de sua condição de uso e finalidade e instaurá-lo como obra de arte. Nesse caso, os paralelepípedos deslocados náo teriam mais o estatuto de artefato, nem o de simples matéria para fabricação, já que esta última condição eles já teriam perdido, ao serem utilizados nos calçamentos. 
Um outro possível deslocamento seria copiar um ou mais desses paralelepípedos, ficando a cópia de tal modo próxima que não fosse mais possível distinguir entre a pedra dita original e a pedra copiada, procedimento similar ao de Giusepe Penone, na obra Essere Fiume (a qual será abordada mais adiante). Provocativamente, nesse caso, as duas pedras paralelepípedos - como sugere o próprio nome - seriam apresentadas uma ao lado da outra, deixando em dúvida se ambas seriam efetivamente pedras, se uma seria cópia e, desse modo, mais "artificial" que a outra, se umas delas seria referente, ou se ambas estariam na condição de significantes sem origem do significado.

Mas ainda outros deslocamentos poderiam ocorrer, como, ao desconstruir a ideia de que paralelepípedos devam ser provenientes de pedras naturais: nessa circunstância, poderia ser instalada uma série de pedras ditas artificiais, feitas de materiais sintéticos, como o concreto. Poderia ser produzida, com efeito, uma série homogênea mas não funcional, como as séries minimalistas de Donald Judd. Ou, ainda, recorrendo a um material mais plástico como a argila, poderia se preservar, nos processos de moldagem e queima, a singularidade de cada paralelepípedo no interior da série. Reforçando tal deslocamento, eles poderiam ser instalados com cortes e fragmentaçôes, os quais desconstruiriam a remissão a uma funcionalidade qualquer. 


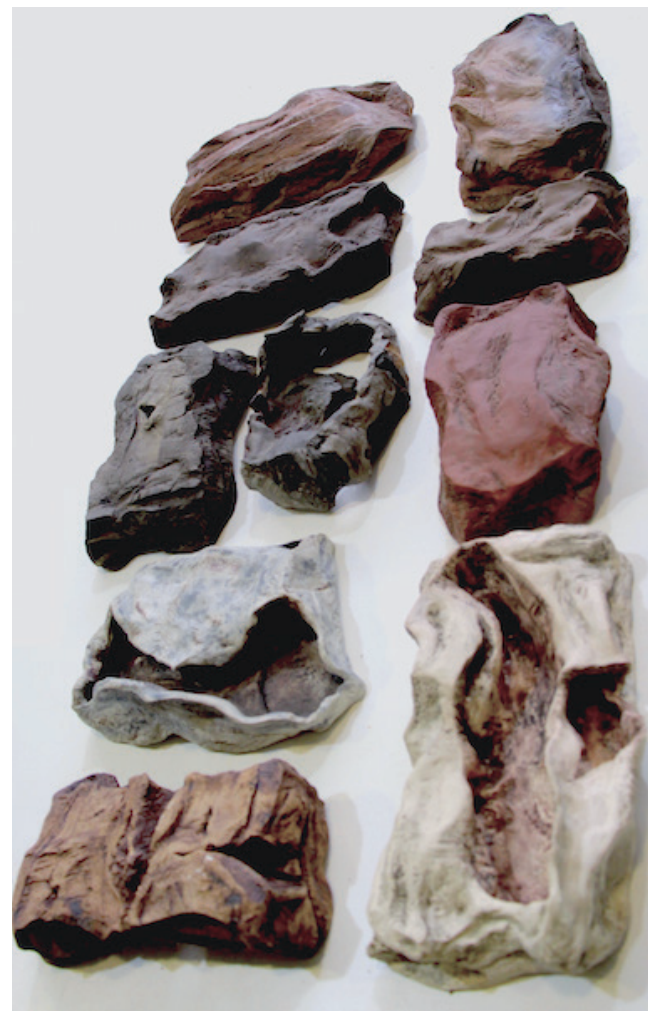

Alice Serra. Paralelepipedos: desconstruçóes (cerâmica), 2015

Será que, na abordagem desses deslocamentos, seria pertinente uma fenomenologia - em sua proposta descritiva e analítica? Ou seria o discurso fenomenológico impróprio, já que, em algumas das possibilidades apresentadas, já seria impossível apontar o "enquanto tal" (das als) do tema em questão, as pedras? Ou seja, na fenomenologia o "enquanto tal” implica realçar um conjunto de aspectos que permitissem, a cada momento, definir e situar a pedra em relação ao que ela não é e manter um núcleo de identidade passível de ser atualizado em suas variaçóes modais. Contudo, na circunstância de uma pedra feita de material sintético ou de uma pedra mimetizando outra pedra ou mimetizando a si mesma, seria ainda possível falar em distinçóes noemáticas, ou seja, a partir de um sentido ideal passível de separar-se das materialidades e das alteraçôes circunstanciais em que se inscreve? 
Com essas questôes, pertinentes a simples pedras, que afinal não são tão simples assim, recorri a alguns autores que se voltaram à relaçáo entre pedra e arte, dentre eles Heidegger, Derrida, Didi-Huberman, Baudrillard e Jean-Luc Nancy, e recorri também a alguns artistas contemporâneos, como Giuseppe Penone, Robert Smithson e Claudi Casanovas, os quais tocam a temática pedras em suas obras. (O que apresentarei, na sequência, é um recorte dessa pesquisa, que foi motivada tanto pelas leituras dos autores mencionados quanto por meu próprio trabalho em cerâmica).

\section{Mera COISA, UTENSÍlIO, OBRA DE ARTE}

Em Origem da obra de Arte (Ursprung des Kunstwerkes), na primeira parte, intitulada "A coisa e a obra", Heidegger distingue entre coisas puramente coisas, coisas-utensílios e coisas que são obras de arte. ${ }^{3}$

Acompanhando a análise de Heidegger, primeiramente se pergunta pelo ser da coisa, a fim de abordar o ser da obra. Conforme Heidegger: "A pedra no caminho é uma coisa, e também o torrão de terra. Mas o que dizer do leite da jarra e da água na fonte? Estes também são coisas." (HEIDEGGER, 2010, \$13). Essas são coisas com as quais lidamos habitualmente, coisas que se encontram à disposição (vorhanden) e à mostração no mundo que nos circunda. Mas Heidegger acrescenta que a noção de coisa (Ding) inclui ainda o que náo aparece, num dos sentidos em que o termo "coisa em si" foi empregado por Kant, como o que está aquém do que aparece (o fenômeno). Além disso, por coisas se entendem não somente as coisas do mundo, mas a "totalidade do mundo". Nesse sentido mais lato, o conceito de coisa abarca tudo o que não é nada e, nesse âmbito, abrange também a arte, "na medida em que [a arte] é uma coisa”. Todavia, essa noção abrangente de coisa não permite delimitar a arte de outras coisas: assim, Heidegger diferencia entre "coisa" (Ding) e "mera coisa" (Blosses Ding), e é nesse âmbito das meras coisas que ele situa precisamente uma pedra, um bloco de granito: "Uma mera coisa (ein blosses Ding) é, por exemplo, este bloco de granito. É duro, pesado, extenso, maciço, disforme, áspero [...]. Toda esta enumeração pode ser percebida na pedra." (HEIDEGGER, 2010, \$18).

\footnotetext{
${ }^{3}$ A leitura deste se limitará, aqui, aos parágrafos $\$ \$ 1$ a 56 da primeira parte, "A coisa e a obra". Ressalto que faço um recorte desse texto heideggeriano, sem abordar a segunda e terceira partes, nas quais Heidegger rejeita a definição de coisa para a arte e examina a arte enquanto acontecimento da verdade. $\mathrm{O}$ recorte se justifica, porque, nessas partes subsequentes, Heidegger não mais se reporta ao tema em questão.
} 
Tais coisas como pedras são meras coisas, segundo Heidegger, "[...] em um sentido quase depreciativo" (HEIDEGGER, 2010, $\$ 15)$ e, além disso, no sentido de que são desprovidas do caráter de serventia e fabricação ( $\$ 37)$. A hierarquia presente no texto situa, assim, em grau mais baixo, o âmbito das meras coisas, no qual se incluem a pedra, o torrão de terra, o bloco de granito etc.; em seguida, Heidegger situa os utensílios, para, enfim, culminar na obra de arte.

O utensílio (das Zeug), por exemplo, o utensílio sapatos, repousa, quando acabado, também em si como a mera coisa, mas ele não tem, como o bloco de granito, uma origem própria. Por outro lado, o utensílio mostra um parentesco com a obra de arte no que ele é um produto do trabalho humano. Todavia, a obra de arte, através de sua presença auto-suficiente, assemelha-se antes à mera coisa, em sua origem própria e não forçada a nada. (HEIDEGGER, 2010, $\$ 33$ ).

Apresentam-se, pois, três diferenciações e duas intercessões: utensílios e obras de arte remetem ao trabalho humano, enquanto tal vínculo não se faz necessário para as meras coisas. Por outro lado, as meras coisas e as obras de arte têm em comum uma autossuficiência que é ausente no utensílio, já que este somente é em relação a uma finalidade e a um uso para os quais foi produzido. Heidegger precisa então reforçar a distinção entre utensílios e obras de arte, no sentido de que é a obra de arte que dá a conhecer aquilo que o utensílio é em verdade. Nisso consiste o cerne do exame de Heidegger sobre um quadro em que Van Gogh pintou sapatos. Heidegger insinua que é na imagem da pintura que o utensílio sapato mostra ser o que em verdade é, na labuta quotidiana do camponês, no copertencimento aos pés que o utilizam e ao campo circundante a qual conduz (HEIDEGGER, 2010, $\$ 46,53$ ).

Derrida (1978a), em Da verdade em pintura (De la verité en peinture), desconstruiu essa leitura em diversos passos: primeiramente, ao lembrar que o quadro a que se referia Heidegger não possuía o título "sapatos de camponês" e nenhuma alusão direta a esse sujeito ou tema (sujet). ${ }^{4}$ Derrida $\left(1978^{a}\right)$ indica que os sapatos estavam desamarrados dos pés que supostamente calçariam,

4 "Ele [Heidegger] vem a essa pintura no decurso de uma distinção entre três modos de ser: os artefacta utilitários (produtos), as coisas naturais e as obras de arte. Ele propóe-se a descrever, a princípio, 'sem nenhuma teoria filosófica' uma espécie familiar de produto (Zeug) - um par de sapatos de camponeses, e, para facilitar a visualização (realização visual, que traduz Veranschaulischung, apresentação intuitiva, sensível), ele escolhe 'um célebre quadro de Van Gogh que frequentemente pintou tais sapatos' [...]". (DERRIDA, 1978a, p. 336). 
não permitindo serem religados, seja a um solo, seja a um sujeito ao qual pertenceriam e, além disso, poderiam náo formar um par de sapatos, estando cada um exposto em sua singularidade.

Mas é ainda um outro ponto que, nesse contexto, interessa desconstruir no enfoque heideggeriano, ou seja: na medida em que separa as três instâncias - meras coisas, utensílios e obras de arte - a distinção heideggeriana é insuficiente para abordar "meras coisas", como pedras - seguindo o exemplo dado pelo próprio Heidegger -, quando estas não têm origem em si, como quando são utensílios, nem quando se apresentam como obras de arte. Além disso, no texto Os conceitos fundamentais da metafísica, Heidegger enuncia que "a pedra é sem mundo", o animal é "pobre de mundo", ao passo que o homem é "configurador de mundo" (HEIDEGGER, 2003, p. 228). Heidegger recusa à pedra (e aliás, também aos animais, a possibilidade de configurar mundo): "[...] em se encontrando sobre a terra, a pedra náo a toca. [...] Onde nenhuma linguagem se faz presente como no ser da pedra, da planta e do animal, também aí não há nenhuma abertura do ente [...].” (HEIDEGGER, 2003, p. 228s.).

Ora, justamente a indelimitação entre pedras enquanto meras coisas e arte e a possibilidade das pedras se espaçarem em diferentes configuraçóes de mundo - tais possibilidades se apresentam em alguns trabalhos em arte contemporânea, como Essere fiume, de Giuseppe Penone, trabalhos vinculados à Land Art e o trabalho em cerâmica de Claudi Casanovas.

\section{DesconstruÇóes em OBRAS}

3.1 Giuseppe Penone ((ItÁla, 1947-)

Giuseppe Penone, em sua obra Essere fiume (“Ser rio", 1981), expóe duas pedras: uma encontrada na natureza, outra por ele esculpida conforme a primeira. 


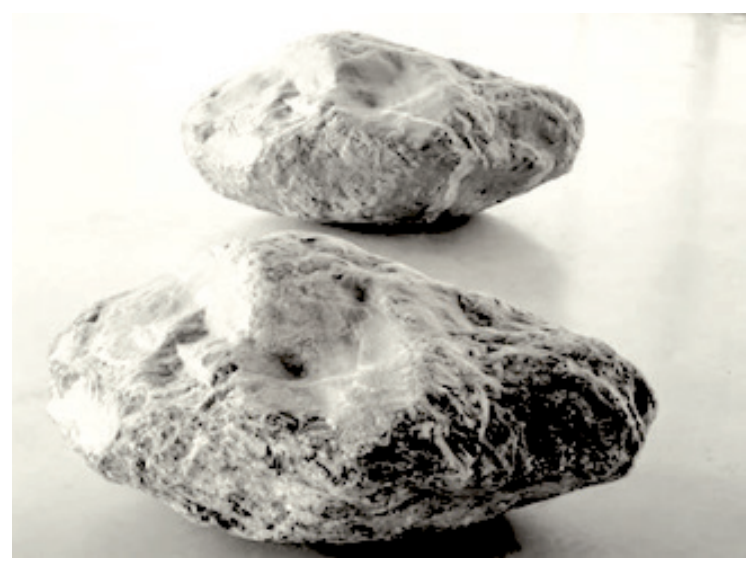

Giuseppe Penone, Essere fiume, 1981

Duas pedras, $40 \times 40 \times 50 \mathrm{~cm}$

Ao comentar esse trabalho, Didi-Huberman, no texto Ser crânio: lugar, contato, pensamento, escultura, insinua que são duas temporalidades aí presentes: "[...] um encontro em um mesmo lugar de duas temporalidades profundamente diferentes (aquela, geológica, da pedra do rio e esta, artística, da pedra da montanha).” (DIDI-HUBERMAN, 2009, p. 53). Mais precisamente, DidiHuberman adverte que são duas pedras encontradas na natureza e não somente a primeira, pois a segunda fora encontrada numa montanha próxima ao rio, antes de o artista mimetizar na escultura o tempo geológico da primeira. A esse tempo geológico Didi-Huberman, citando Penone, alude através de verbos de ação como: "as pedras se chocam, explodem", "a água lava, leva a poeira de pedra, pule o material.” (2009, p. 46). É como se o escultor se aproximasse desses procedimentos, já que, como ressalta Penone, no título que deu à obra, há que ser rio para esculpir a pedra: "Para esculpir a pedra de verdade, temse que ser rio." (PENONE apud DIDI-HUBERMAN, 2009). O artista, no esculpir, torna-se, desse modo, o sujeito implícito a estes infinitivos: lavar, levar a poeira, polir. ${ }^{5}$ Como sugere Didi-Huberman, na primeira pedra, tem lugar uma "ontogênese material da forma", enquanto, na segunda, "[...] a escultura tem então valor de uma anamnese em atos, em pedra, em tempo presente." (DIDI-HUBERMAN, 2009, p. 47, 54). Essa anamnese, que não é memória de si, é uma memória suposta acerca dos processos, lentos e imperceptíveis, de

\footnotetext{
${ }^{5}$ Também Richard Serra propõe uma lista de infinitivos semelhante, para aludir a certos processos da escultura.
} 
desgaste e outros, que deram forma à pedra. Tem-se, assim, uma anamnese que carece de memória contínua e que, a partir de marcas encontradas, permite supor os processos e açôes decorridos. Ou seja, supóe-se o que se imita; o que se afirma é tanto menos o sujeito que lembra - o escultor - ou o sujeito que é lembrado - o rio -, e tanto mais aquilo que, em função desses supostos sujeitos, reafirma-se, repetindo e, nisso, diferindo-se.

Derrida, em seu livro Memórias de cego, remete-nos a essa "memória sem memória", ao aludir ao simples ato de desenhar, o que pode também ser pensado relativamente ao esculpir:

Improvisada ou não, a inscriçáo do traço náo segue, não se regula pelo que é presentemente visível, e estaria ali pousado, diante de mim, como um tema. Mesmo se o desenho é mimético, como se diz, reprodutivo, figurativo, representativo, mesmo se o modelo está diante do artista, é preciso que o traço proceda na noite. Ele escapa ao campo de visáo. Não somente porque não é ainda visível, mas porque não pertence à ordem do espetáculo, da objetividade especular - e aquilo que ele faz advir não pode ser mimético em si. (DERRIDA, 2010, p. 51s.).

Haveria assim que considerar, mesmo no procedimento "mimético" de Penone, esses espaçamentos entre o que se vê, o que decorreu anteriormente e o que se torna, inscrito na pedra, no papel etc. A mimesis mostra ser, nesse sentido, uma nostalgia de origem que não se cumpre. Com Derrida, pode-se dizer que o traçado, o entalhe, a lapidação etc. "procede $[\mathrm{m}]$ na noite", ao se inscreverem transpondo o olhar perceptivo e ao inscreverem o que escapa a esse olhar. O tempo presente dá lugar a uma ruína no presente, alusiva a um outrora sem datação.

No começo há a ruína. Ruína é o que acontece aqui à imagem desde o primeiro olhar. Ruína é o auto-retrato, este rosto fitado ou desfigurado como memória de si, o que resta ou retorna como um espectro desde que, ao primeiro olhar sobre si lançado, uma figuração se eclipsa. (DERRIDA, 2010, p. 71).

Nesse sentido, a primeira pedra encontrada pode ser lida como fragmento ou resto de um processo não mais passível de ser reconstituído. Já a segunda pedra é também um fragmento, o que restou de um bloco maior, mas cuja origem não mais se restitui. Nesse caso, a pretensão de uma imagem referencial vê-se ameaçada pela dimensão espectral que faz com que, no cerne 
do perceptivo, insurja o náo perceptivo. Uma pedra ou outra, ou ainda ambas, trariam esses espectros de montanha, rio, paisagem natural. Contudo, além disso, haveria outros tantos espectros contaminando e contrariando a relação mimética ou representativa.

Desse modo, o trabalho Essere Fiume desconstrói, por si mesmo, a dicotomia entre original e cópia, matéria natural e forma artística, atividade subjetiva e passividade da matéria. Mas uma tendência diferente desta aparece, quando se dilui a relação referencial, de sorte que coisas como pedras possam ser apresentadas como tais. Assim, a questão sobre a relação entre referência e referente desdobra-se como diferença entre matéria natural e matéria artificial.

\subsection{Robert SMITHSON (EUA, 1938 - 1973)}

Para os artistas vinculados à Land Art (tendência que afirma o vínculo entre natureza e arte) ${ }^{6}$, os deslocamentos, desgastes e fragmentaçóes dos materiais ditos naturais foram realçados, dando a ideia de que, ou as obras são sem referente, ou esse referente diz respeito tão somente aos materiais naturais que precisamente coincidem com os materiais expostos. Para tais artistas, a separação entre materiais ditos naturais e materiais não naturais permaneceu como um critério para diferenciar o que se privilegiaria em arte. Nesse caso, pedras como tais somente podem ser pedras de natureza.

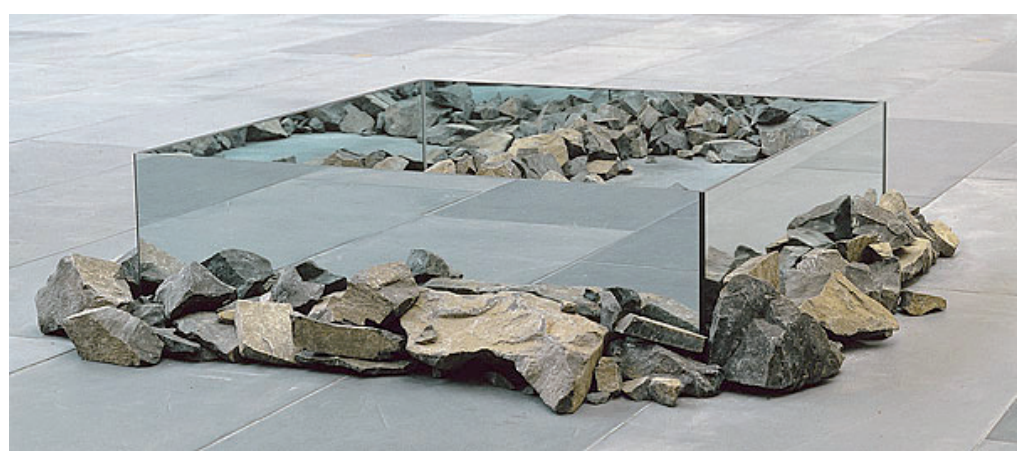

Robert Smithson, Rocks and mirror square II

Robert Smithson, no texto "Uma sedimentação da mente: projetos de terra” (2006), cita o fragmento 124 de Heráclito: "O mundo mais belo é como

${ }^{6}$ Especialmente em trabalhos desenvolvidos a partir dos anos 1970, nos Estados Unidos. 
um monte de pedras lançado em confusão" (SMITHSON, 2006, p. 184). Ao que Smithson contrapóe o universo urbano: "A cidade dá a ilusão de que a terra não existe." (SMITHSON, 2006, p. 184). Smithson, assim como Michael Heizer e outros artistas vinculados à Land Art, engajavam-se em obras que trouxessem a natureza à mostração, uma natureza processada pela intervenção dos artistas, mas, ainda assim, sempre que possível, conservada em locais ditos naturais ou afastados dos centros urbanos. A própria noção de ocupação de um espaço de natureza, de um território vazio, desabitado, afirmava a não demarcação prévia do espaço da arte, como indica Cauquelin (2005, p. 143). Ou senão, mesmo quando instaladas em nichos urbanos, obras da Land Art revelavam uma reassunção da natureza em detrimento do que a transforma ou desconfigura. Se há desconfiguração, erosão, sedimentação etc., estes são processos que eclodem a partir dos próprios materiais, como uma espécie de "memória sobre memória" (ARCHER, 2008, p. 98). Parafraseando o título de um trabalho de Smithson, "Piscina de cascalho e alcatrão", esses processos se deixariam designar: memória de terra sobre memória de terra, memória de pedra sobre memória de pedra, ou ainda outras variaçôes.

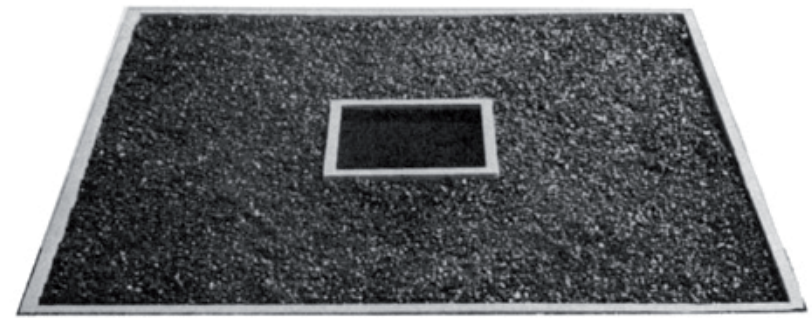

Robert Smithson, Tar Pool and Gravel Pit (model), 1966

Nas palavras de Smithson, seus trabalhos pretendem, tanto quanto possível, permanecer livres de "sugestôes antropomórficas" (SMITHSON, 2006, p. 184). Isso se veria em propostas como a exposição de terras dispostas em montes, gesso "sem organização manual" (OPPENHEIM apud SMITHSON, 2006, p. 184), cascalho e alcatrão em sedimentação, remetendo a uma espécie de "limo primordial". S Smithson apresenta propriamente a analogia entre níveis mais baixos da consciência e estados primordiais de materiais em decomposição ou em sedimentação:

\footnotetext{
${ }^{7}$ Nesse caso, a obra referente de Smithson é Tar Pool and Gravel Pit (Piscina de alcatrão e poço de cascalho, 1966).
} 
A mente e a terra encontram-se em um processo constante de erosão: rios mentais derrubam encostas abstratas, ondas cerebrais desgastam rochedos de pensamento, ideias se decompóem em pedras de desconhecimento, e cristalizaçôes conceituais desmoronam em resíduos arenosos de razão. (SMITHSON, 2006, p. 182).

Aqui a analogia pretensa não se dá entre um elemento natural e outro quase-natural ou esculpido - como em Essere fiume. Têm-se, antes, ordenações de materiais ditos naturais em dissolução, decomposição etc., processos semelhantes aos que ocorreriam em níveis mais arcaicos da "mente". Em sua conotação tópica, níveis mais arcaicos remetem ao que se sedimenta em camadas mais profundas, permanecendo, tanto quando possível, livres das influências de conexôes mais recentes. Em contrapartida, Smithson apresenta a analogia entre processos mais refinados de pensamento e processamento tecnológico, analogia que lhe permite justificar a escolha e a exclusão de certos materiais de seus trabalhos: Smithson recusa materiais processados tecnologicamente, já que estes se contraporiam ao desuso e desgaste naturais.

O rompimento ou fragmentação da matéria chama a atenção para o substrato de Terra, antes de ela ser excessivamente refinada pela indústria para se tornar metal laminado, vigas, perfis de alumínio, tubos, fios, canais, liga de aço, barras de ferro etc. (SMITHSON, 2006, p. 189).

Por esses jogos analógicos de Smithson, perguntar-se-á, todavia, se é possível manter o mais arcaico livre das interferências do menos arcaico, e se é possível manter a distinção entre materiais ditos naturais e materiais artificiais. Ambas as possibilidades se mostram questionáveis, com base em Baudrillard.

Acerca da madeira ou da pedra pensadas como produtos naturais comparados a materiais sintéticos, Baudrillard aponta que essa oposição (substância natural/substância sintética) é tão somente moral ou ideológica:

Obviamente as substâncias são o que são: não existem verdadeiras ou falsas, naturais ou artificias. Por que o concreto seria mais 'autêntico' que a pedra? [...] No fundo a nobreza hereditária da matéria existe somente por uma ideologia cultural análoga à do mito aristocrático na hierarquia humana, e mesmo este preconceito cultural declina com o tempo. (BAUDRILLARD, 2009, p. 45). 
Conforme Baudrillard, a oposição entre natural e sintético é, pois, construída e valorativa. Assim, o uso de materiais sintéticos, polimorfos, não seria sinônimo de empobrecimento:

[...] a fabricaçáo sintética significa para o material um desprendimento de seu simbolismo natural em direção a um polimorfismo, grau de abstração superior onde se torna possível um jogo de associação universal de matérias e pois uma superação da oposição formal matérias naturais/matérias artificiais. (BAUDRILLARD, 2009, p. 45).

Tais possibilidades de jogos expressivos por uma matéria que não é puramente natural nem puramente artificial podem ser vistas no trabalho de Claudi Casanovas.

\subsection{Claudi Casanovas (Espanha, 1956-)}

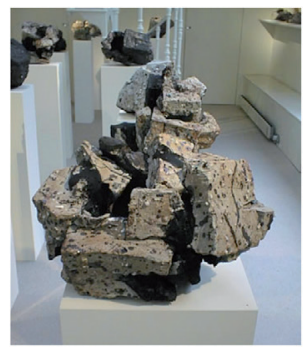

Claudi Casanovas

Block no. 17, cat 9 $36 \times 24 \times 27 \mathrm{~cm}$

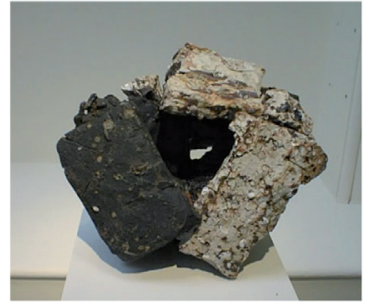

Claudi Casanovas

Block no. 48 , cat 14 $23 \times 28 \times 27 \mathrm{~cm}$

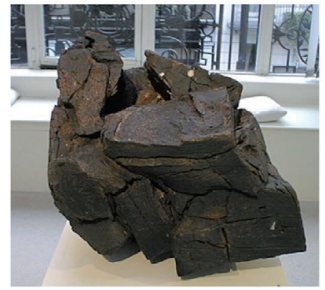

Claudi Casanovas Block no. 59, cat 1 $32 \times 28 \times 21 \mathrm{~cm}$

Obras de Casanovas, como Blocks e Memorial als Vençuts, trazem objetos de cerâmica como se estes remetessem à matéria da qual provêm: formas orgânicas inacabadas, plenas de rachaduras ou fraturas, contornos indefinidos ou dissonantes. É como se o artista não somente transformasse a matéria, mas a expusesse a uma tessitura de riscos, incisóes, cortes, que lhe devolvesse algo de próprio. É como se a obra despertasse possibilidades dormentes, possíveis mutaçóes geológicas que encontram, através do artista, algumas de suas efetivaçôes. Nesse sentido, as fraturas e tonalidades advindas da argila na queima menos a elevariam a uma segunda natureza, a uma condição de obra 
artística enquanto objeto de cultura, do que lhe restituiria a um espaçamento próprio, anterior aos significados e individuaçóes.

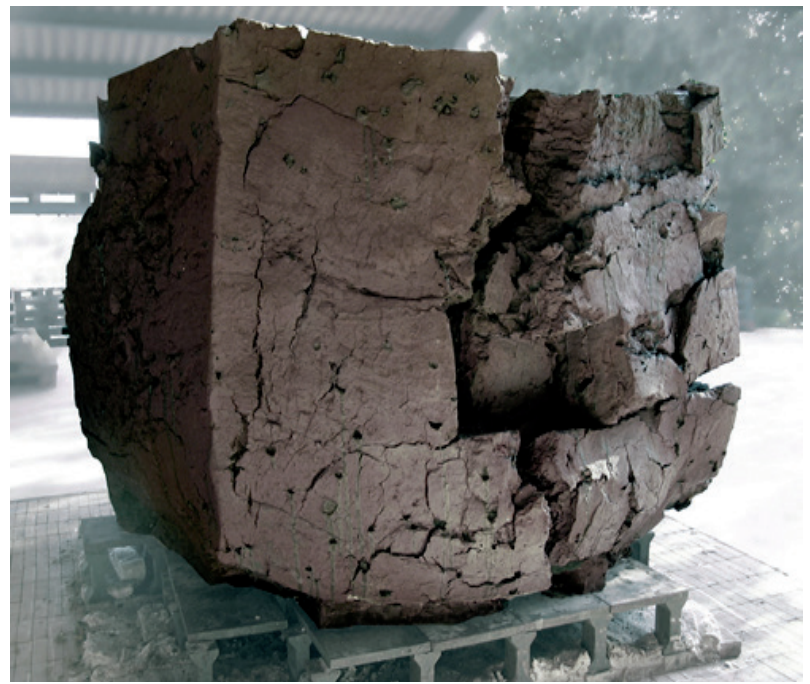

Claudi Casanovas, Memorial als Vençuts, 2004 (criado num período de dois anos a partir de 15 toneladas de argila e envolto por uma cápsula de concreto)

Em "Memorial aos vencidos", por exemplo, a argila tanto aparenta mimetizar materiais ditos naturais, como pedras e torrôes de terra, quanto indica mimetizar ou encenar a si mesma (lembrando que uma massa de argila queimada em temperatura integra de tal modo a terra sob a determinação do calor, que se torna pedra ${ }^{8}$ ). É como se o grande bloco de argila constrangesse o espectador a olhar para o que aparece: o que se vê não é argila que mimetiza ou representa outra coisa, mas a própria argila queimada. Esse trabalho lembra, pois, o pressuposto minimalista de Frank Stella, segundo o qual "o que se vê é somente o que se vê" - mas, precisando: apenas lembra.

Como conhecido, o minimalismo reagiu a concepçóes do ilusionismo e simbolismo em artes visuais, segundo os quais os materiais expostos teriam a função de significantes de significados ou de ideias transcendentes aos objetos expostos. Ao afirmar a "externalidade do significado", o minimalismo pretendeu instaurar séries centrípetas, as quais continham em si mesmas suas relaçóes referenciais, suas coesóes, ordens ou tensóes (KRAUSS, 2007, p.

${ }^{8}$ Devo esta consideração a Betânia Silveira. 
318). Dessa forma, os objetos deixam de ser materiais que expressam ou que aludem a uma "vida interior da forma”, em direção a disposiçôes horizontais, que implodem a hierarquia entre matéria e forma, referência e referente etc. (KRAUSS, 2007, p. 300s.).

Todavia, no caso do trabalho Memorial als Vençuts, instaura-se um bloco de argila que foi queimado, o qual passou por um processo de transformação para conservar-se. Entre a opacidade da obra - sua capacidade de remeter somente a si e preservar sua singularidade - e a transparência da obra - ou seja, o complexo de significaçóes que uma obra evoca ou que lhe advém (BOEHM, 2015), há um resto de materialidade que resiste ao movimento de significação. Reflexōes de Derrida nos possibilitam pensar, nesse sentido, em uma espécie de memória matérica.

\section{Pedras, rastro, mundo: desconstruÇóes}

Para Derrida, teria sido Freud quem instituiu a questão da memória que é debaixo (dessous): mais abaixo da consciência, ela não possui a visibilidade dos objetos ou das representaçóes conscientes. Essa memória - salienta Freud, no Projeto de uma psicologia e, logo depois, numa carta a Fliess - não se faz presente de uma só vez, mas se deposita em sobreposiçóes de diferentes trilhamentos ou inscrições (FREUD, 1986; 1987). Tudo o que é percebido ou sentido se fragmenta assim segundo trilhamentos (Bahnungen) que se constituem quer a partir daquilo que nos chega do mundo exterior pela sensibilidade, quer daquilo que, procedendo do interior, sobredetermina o que se registra.

Conforme a leitura de Derrida acerca dessa formulaçáo de Freud, seja aquém da consciência, seja em diversos âmbitos da escritura, instauram-se redes de rastros (traces) ou traços (traits) diferenciais que se modificam a cada nova inscrição (DERRIDA, 1967). As camadas de inscriçóes que se fazem a partir dessas diferenciaçóes só se deixam ler a posteriori, de modo que a temporalidade das inscriçóes não coincide com a temporalidade daquele - $\mathrm{o}$ sujeito - que lê inscriçóes. Em outras palavras, há uma escritura (écriture) não diretamente legível, uma tessitura de rastros e traços que apenas se faz visível de modo diferenciado em relaçấo à sua origem.

Em seus Escritos sobre as artes do visivel - ou "artes do espaço", como prefere denominá-las -, Derrida (2012a) retoma o pensamento do traço diferencial para desconstruir a noção de origem da arte e para aludir aos 
debaixos (les dessous) da obra de arte: os debaixos remetem ao que, embora não diretamente visível na superfície, é constitutivo da obra e precisa ser pensado e considerados. Isso implica rever continuamente os limites entre o que é obra e o que não é obra, entre ergon (obra) e parergon (o que é em torno ou junto à obra). Tais limites são moventes, não passíveis de determinação estanque (DERRIDA, 1978b). Os debaixos aludem primeiramente aos suportes ditos materiais, ou seja, o papel, a tela, a madeira ou tecido sobre os quais a imagem se instala. Os debaixos aludem também a instâncias subjacentes de outros tipos, como a circulação econômica, os bastidores políticos, a sedimentaçáo de interpretaçôes que podem parecer invisíveis na superfície da obra ou que, de maneira sutil, podem confundir-se com a imagem da obra. Os debaixos ou suportes incluem assim tudo o que em relação à obra e com base na obra inscreveu-se nela de algum modo. (SERRA, 2014).

Por sua vez, em diálogo com Heidegger e reportando aos quaseconceitos derridianos de debaixos e rastreamentos, Jean-Luc Nancy, na obra Le sens du monde ( $O$ sentido do mundo), assinala a insuficiência do cogito, quando este se investe das funçóes de apropriação, determinação e neutralização da alteridade do contato entre materialidades:

Por que, pois, o "acesso" seria determinado a priori pelo modo da identificação e da apropriação da "outra coisa"? Quando eu toco outra coisa, uma outra pele, que este contato esteja em jogo, e não em uso instrumental, tratar-se-ia de identificá-lo e de dele se apropriar? [...] Ou ainda: por que seria preciso determinar a priori o "acesso a" como o modo necessário de um fazer-mundo e de um ser-no-mundo? [...]

A Heidegger falta o peso (o pensamento?) da pedra somente desdobrada ou tocante sobre o solo, o peso do contato da pedra com outra superfície, e desta com o mundo enquanto rede de outras superfícies. (NANCY, 1993, p. 100s., tradução nossa).

É assim que Nancy (1993, p. 100s) enfatiza o contato, incluindo o contato da pedra que toca a terra, que pode tocar outra pedra, outro cháo, outras superfícies. Nancy remete, aqui, à citada consideração de Heidegger, em Os conceitos fundamentais da metafísica (2003, p. 228), na qual este enuncia que "a pedra é sem mundo", o animal é "pobre de mundo", enquanto o homem é "configurador de mundo". Como indica Nancy, Heidegger teria determinado apenas negativamente o tocar da pedra em outros corpos ou matérias: como citado, "[...] a Heidegger falta o peso (o pensamento?) da 
pedra." De modo interessante, nessa passagem, Nancy joga com os termos peso e pensamento, que em francês são quase homônimos, respectivamente, pesée e pensée. Todavia, o autor deixa pensamento em interrogação ou ambiguidade, ou seja, num primeiro sentido, Heidegger não teria pensado suficientemente o peso, a materialidade da pedra, ao retirá-la da possibilidade de configurar mundo, de tocar e ser tocada. Nesse caso, Nancy (1993, p. 102) precisa que a pedra não simplesmente "tateia" (betastet, em alemão), mas ela "toca" (touche) e, mais propriamente, "toca em" (touche à) e, nisso, simultaneamente, é tocada (est touchée). Ou seja, também à pedra seria pertinente a abordagem fenomenológica do corpo tocado-tocante, o qual repensa a constituição transcendental para além da primazia da consciência intencional subjetiva (HUSSERL, 1966). Já num segundo sentido, é como se, em Heidegger, fosse também insuficiente o pensar da pedra. Mesmo que deixando em interrogação "(o pensamento?) da pedra", Nancy desvela aqui um insuficiente pensar "a partir" do que se instaura a cada vez pela pedra. Nas palavras de Nancy (1993, p. 102): "A pedra náo tem sentido, mas o sentido toca à pedra: ele aí mesmo se choca $[. .$.$] ."$

Nessa acepção, a pedra deixa de ser sem mundo ou pobre de mundo, já que ela instaura relaçóes e rastros, extensôes e temporizaçôes-espaçamentos, exerce pressão em outros corpos, outros seres, tenciona, distende. Insinua-se assim a ideia de que, se as pedras não são meros objetos à disposição para o consumo e manuseio, essa disponibilidade (Vorhandenheit) também não se presta ao conceito. É, antes, o pensamento que se afeta pelo ser-outro e que, desde essa interferência do outro, se desloca de seu centro e identidade pretensos ou abstratos.

Finalizo, nesse sentido, com uma passagem do texto de Derrida em Che cosè la poesia?, alusiva à alteridade que está na marca singular não passível de idealização, e que pode estar numa pedra, num animal, num poema:

De agora em diante, você chamará poema uma certa paixão da marca singular, da assinatura que repete sua dispersão, a cada vez, além do logos, a-humana, dificilmente doméstica, nem mesmo reapropriável na família do sujeito: um animal convertido, enrolado em bola, voltado para o outro e para si, uma coisa em suma, modesta, discreta, próxima da terra [...]. (DERRIDA, 2001, p. 113-115). 
SERRA, Alice. Mere things and spatial arts: deconstruction in works. Trans/Form/Ação, Marília, v. 39, p. 111-132, 2016. Edição Especial.

\begin{abstract}
This text approaches some contemporary works in the visual arts (works by G. Penone, R. Smithson, C. Casanova) which present different relations and dispositions of a material taken to be natural: stone. I intend to revisit the distinctions presented by Heidegger between mere things, utensils and works of art, as well as between stone, animal and man in connection with the world. Furthermore, I will discuss dislocations regarding such issues, based on indications from deconstruction (Jacques Derrida and other authors). I aim to indicate some of the meanings under which deconstructive approaches are fruitful for thinking about contemporary movements within the scope of what Derrida calls "spatial arts".
\end{abstract}

KEYWORDS: Visual arts. Heidegger. Deconstruction. Derrida.

\title{
REFERÊNCIAS
}

BAUDRILlARD, Jean. O sistema dos objetos. Tradução de Luiz R. S. Fortes. Sáo Paulo: Perspectiva, 2009.

BOEHM, G. Aquilo que se mostra: sobre a diferença icônica. Tradução de Carla Rodrigues. In: ALLOA, E. (Org.). Pensar a imagem. Tradução de C. Rodrigues, F. Fragozo, A. Serra, M. Poyares. Belo Horizonte: Autêntica, 2015. p. 23-38.

DERRIDA, J. Freud et la scéne de l'écriture. In: L'écriture et la différence. Paris: Éditions du Seuil, 1967. p. 293-340. . La différance. In: . Marges de la philosophie. Paris: Minuit, 1972. p. 1-30. . Restitutions de la vérité en pointure. In: De la verité en peinture. Paris: Flammarion, 1978a. p. 291-436.

. Le parergon. In: De la verité en peinture. Paris: Flammarion, 1978b. p. 44-94.

. Che cos'è la poesia? Tradução de Tatiana Rios e Marcos Siscar. Inimigo Rumor, v. 10, p. 113-116, 2001. (Texto publicado em Points de Suspension. Paris: Galilée, 1992, p. 303-308).

. Memórias de cego: $\mathrm{O}$ auto-retrato e outras ruínas. Tradução de Fernanda Bernardo. Lisboa: Fundação Calouste Gulbenkian, 2010.

Os debaixos da pintura, da escrita e do desenho: suporte, substância, sujeito, sequaz e suplício. In: MICHAUD, G.; MASÓ, J.; BASSAS, J. (Org.). Pensar em não ver: escritos sobre as arte do visível (1979-2004). Tradução de Marcelo J. Moraes. Florianópolis: Editora da UFSC, 2012a. p. 279-295. 
As artes espaciais: uma entrevista com Jacques Derrida. In: MICHAUD, G.; MASÓ, J.; BASSAS, J. (Org.). Pensar em não ver: escritos sobre as arte do visível (19792004). Tradução de Marcelo J. Moraes. Florianópolis: Editora da UFSC, 2012b. p. 17-62.

DERRIDA, J.; BERGSTEIN, L. Enlouquecer o Subjétil. Tradução de Geraldo G. de Souza. São Paulo: Fundação Editora da UNESP, 1998.

DIDI-HUBERMAN, G. Ser crânio: lugar, contato, pensamento, escultura. Tradução de Augustin de Tugny e Vera Casa Nova. Belo Horizonte: C/Arte, 2009.

FREUD, S. Briefe an Wilhelm Fließ 1887-1904. Organizado por J. M. Masson. Frankfurt: Fischer, 1986.

. Entwurf einer psychologie (1895). In : GW Nachtragsband: Texte aus den Jahren 1885-1938. Frankfurt: Fischer, 1987. p. 373-486.

HEIDEGGER, M. Os conceitos fundamentais da metafísica: mundo, finitude, solidão. Tradução de M. Casanova. Rio de Janeiro: Forense Universitária, 2003.

. Origem da obra de arte. Tradução de Idalina Azevedo e Manuel A. Castro. São Paulo: Ediçóes 70, 2010. \$\$ 27-56.

HUSSERL, E. Hua XI: Analysen zur passiven synthesis. Aus Vorlesungs- und Forschungsmanuskripten 1918-1926. Hrsg. von M. Fleischer. Den Haag: Martinus Nijhoff, 1966.

KRAUSS, R. Caminhos da escultura moderna. Tradução de Julio Fischer. São Paulo: Martins Fontes, 2007.

NANCY, J.-L. Le sens du monde. Paris: Galilée, 1993.

SERRA, A. Imagem e suporte: Fenomenologia e desconstrução. Revista Ek-stasis, v. 3, p. 25-42, 2014.

SMITHSON, R. Uma sedimentação da mente: projetos de terra. In: FERREIRA, G.; COTRIM, C. (Org.). Escritos de artista: anos 60/70. Rio de Janeiro: Zahar, 2006. p. 182-197.

Recebido / Received: 07/06/2016

Aprovado / Approved: 11/08/2016 
SERRA, A. 